\title{
Implementing Programme Related to Gender Inclusion on Local Government in Nepal
}

Sijapati, D. B. (M. Phil.)*

\section{Abstract}

This article focuses on practice of the gender inclusion in local government based in Lalitpur and Jhapa districts of some local level. It is find out practises of gender inclusion police of local level and to explore the practises on the different development paradigm. This article used in different type's of methods and data collection procedure. Basically, information needs to answer the research queries are collected from primary and secondary sources of information. The construction questionnaire for information is collected through the literature review and several qualitative and quantitative approaches. At last SPSS (Statistical Package for the Social Science is used to compute the data. Among the total respondents, 35.3 percent are participation for plans formulation related to income generation progarammes, 31.4 percent plans are related to empowerment and leadership programmes, 21 percent plans are related to gender awareness and violence and only 2 percent plans are related to save cyber-crime. More than 6 percent respondents said that only ward representatives are involved in planning of program activities, 31.4 percent respondents said that only municipality authorities and ward representatives are involved and 59.3 percent respondents said that the local government representatives and all social activist are involved in planning of different program activities. Empirical evidence shows that gender inequality, including from legal gender-related restrictions, leads to the loss of growth opportunities, particularly in countries at earlier stages of development. The adverse effect of legal barriers to women's participation in economic activities remains significant for countries at different stages of development.

Key words: Gender inclusion, policy, programme, empowerment \& decision making.

\section{Introduction}

The gender equality, equality between men and women, entails the concept that all human

${ }^{*}$ Mr. Sijapati is a Lecturer at the Department of Population Studies, Patan Multiple Campus, TU, Lalitpur, Nepal. Email: sijapatidipendra@gmail.com 
beings, both men and women, are free to develop their personal abilities and make choices without the limitations set by stereotypes, rigid gender roles and prejudices. Gender equality means that the different behavior, aspirations and needs of women and men are considered, valued and favored equally. It does not mean that women and men have to become the same, but that their rights, responsibilities and opportunities will not depend on whether they are born male or female. Gender equity means fairness of treatment for women and men, according to their respective needs. This may include equal treatment or treatment that is different but which is considered equivalent in terms of rights, benefits, obligations and opportunities (ILO, 2000). UNICEF (2011), gender quality means that women and men, and girls and boys, enjoy the same rights, resources, opportunities and protections. It does not require that girls and boys, or women and men, be the same, or that they be treated exactly alike.

As defined by the United Nations (2013), gender equality refers to the equal rights, responsibilities and opportunities of women and men and girls and boys. The Department of Economic and Social Affairs of the United Nations defined Social exclusion as the involuntary exclusion of individuals and groups from society's political, economic and social processes, which prevents their full participation in the society in which they live. Gender equality and social inclusion are seen as not only a fundamental aspect of human rights and social justice but also a precondition to improve the development process by putting social concerns at the forefront of interventions. It contends that the reality of power relations in framing the relations between men and women demands the political nature of the project and draws attentions to the areas where movements for rights are being waged. White (1996) argues that both the participation and gender as the political issues are translated into a technical problem which the development enterprise can accommodate with barely a falter in its pace The Gender and Development (GAD) approach focuses on the socially constructed differences between men and women and the need to challenge existing gender roles and relations (Armendáriz, 2010). This approach was majorly influenced by the writings of academic scholars such as Oakley (1972) and Rubin (1975), who emphasize the social relationship between men and women (Moser, 
1993). These relationships, they argue, have systematically subordinated women. GAD departs from WID, which discussed women's subordination and lack of inclusion in discussions of international development without examining broader systems of gender relations. Influenced by this work, by the late 1970s, some practitioners working in the development field questioned focusing on women in isolation. GAD challenged the WID focus on women as an important 'target group' and 'untapped resources' for development (Moser, 1993). In an attempt to create gender equality, (denoting women having same opportunities as men, including ability to participate in the public sphere (Razavi $\&$ Miller, 1995). GAD policies aims to redefine traditional gender role expectations. Women are expected to fulfil household management tasks, home based production as well as bearing and raising children and caring for family members. The role of a wife is largely interpreted as 'the responsibilities of motherhood'. Men however, are expected to be breadwinners whom are associated with paid work, and market production. In the labour market, women tend to earn less than men. For instance, 'a study by the Equality and Human Rights Commission found massive pay inequities in some United Kingdom's top finance companies, women received around 80 percent less performance-related pay than their male colleagues (Armendáriz, 2010). Gender equality, women and men and their similarities and differences are recognized and equally valued. Men and women enjoy equal status, recognition and consideration (GESI, 2017).

This article fulfill in this research questions, what are the practical situation of gender inclusiveness on development issues and paradigm on the basic of local government among the elected local body?

\section{Objectives}

- To find out the practice of gender inclusion of local level.

- To explore gender inclusion issues are sifted to practises on development programmes. 


\section{Methods}

In this article, descriptive and exploratory research design, and quantitative method used for data collection procedure. Basically, information needs to answer the research queries are collected from primary and secondary sources of information. Direct interview is conducted with the respondents (local government elected members) applying the semi-structured questionnaires through census survey method. Face to face interview method has been use to collect the information by designed questionnaire. Researcher had conducted interview with Local Government personnel 45 in Gauradaha Municipality, 25 in Gaurigunj Gaunpalika, 55 in Shiva Satachhi Municipality of Jhapa District, and 134 in Lalitpur metropolitan city 24 in Konjomsom Gaunpalika and 70 in Gadawari Municpality of Lalitpur District. Qualitative information are analyzed through comparative logical analysis. Quantitative data collected through semi-structured questionnaire are analyzed using SPSS (Statistical package for social sciences). The data entered into SPSS database and results are obtained by frequency distributions and cross tabulations.

\section{Results and Discussion}

This article analyzed and interpreted the practice of gender inclusion and inclusiveness in local government by various characteristics i.e. districts, election areas, caste/ethnic groups, level of education, broad age groups and sex.

Table 1: Percentage distribution of respondents by number of meeting reported held to discuss about gender inclusiveness during the last one year by sex

\begin{tabular}{|c|c|c|c|c|c|c|}
\hline \multirow{3}{*}{ Time of meeting } & \multicolumn{5}{|c|}{ Sex of the respondents } & \multirow{3}{*}{$\begin{array}{c}\text { Female per } \\
100 \text { males }\end{array}$} \\
\hline & \multicolumn{2}{|c|}{ Male } & \multicolumn{2}{|c|}{ Female } & \multirow[t]{2}{*}{ Total } & \\
\hline & No. & $\%$ & No. & $\%$ & & \\
\hline \multicolumn{7}{|l|}{ Lalitpur } \\
\hline Need based & 77 & 21.8 & 47 & 13.3 & 35.1 & 61.0 \\
\hline One time in a month & 58 & 16.4 & 36 & 10.2 & 26.6 & 62.0 \\
\hline Two times in a year & 3 & 0.8 & 2 & 0.6 & 1.4 & 67 \\
\hline \multicolumn{7}{|l|}{ Jhapa } \\
\hline Need based & 78 & 22.1 & 52 & 14.7 & 36.8 & 67 \\
\hline
\end{tabular}




\begin{tabular}{|l|r|r|r|r|r|r|}
\hline Metropolitan City & & & & & & 69 \\
\hline Need based & 32 & 9.1 & 22 & 6.2 & 15.3 & 57 \\
\hline One time in a month & 51 & 14.4 & 29 & 8.2 & 22.7 & \\
\hline Two times in a years & & & & & & \\
\hline Municipality & & & & & & 62.2 \\
\hline Need based & 90 & 25.5 & 56 & 15.9 & 41.4 & 100 \\
\hline One time in a month & 7 & 2.0 & 7 & 2.0 & 4.0 & 67 \\
\hline Two times in a year & 3 & 0.8 & 2 & 0.6 & 1.4 & 64 \\
\hline Rural Municipality & & & & & & 0 \\
\hline Need based & 33 & 9.3 & 21 & 5.9 & 15.3 & 0 \\
\hline One time in a month & 0 & 0.0 & 0 & 0.0 & 0.0 & 0.0 \\
\hline Two times in a year & 0 & 0.0 & 0 & 0.0 & 0.0 & \\
\hline
\end{tabular}

Source: Field Survey, 2076.

In district analysis, 35.1 percent respondents of Lalitpur district said that they $\mathrm{h}$ ave practice of conducting meeting and general assembly as need based, 26.6 percent said that one time in a month and only 1.4 percent respondents said two times in a year. Highest percent respondent said that they used to conduct the type of meeting and assembly as need based. Same way, while analyze of Jhapa district, 36.6 percent respondents said that they have practice of organizing the meeting and general assembly on gender inclusion as need based (table 1). As a sex, nearly 22 (21.8) percent male and 13.3 percent female of Lalitpur district said that they are calling meeting and general assembly as need based. 16.4 percent male and 10.2 percent female said that they calls meeting and general assembly one time in a month and 0.8 percent male and 0.6 percent female said that they calls meeting and general assembly two times in a year. Same way, all respondents of Jhapa district said they call meetings and general assembly as need based. Comparing to two districts, Lalitpur district calls more meeting and general assembly than Jhapa district.

As sex ratio, 61 female in 100 female of Lalitpur district said that they use to organize the meeting and general assembly as need based, 62 female in 100 male said that they organize meeting and general assembly one time in a month and 67 female in 100 male 
said they organize two times in year. However, highest sex ratio said that they organize two times in a year (table 1). As election areas, 9.1 percent male and 6.2 percent female of metropolitan city said that they call meeting and general assembly as a need based. 14.4 percent male and 8.2 percent female said that they call the meeting and general assembly one time in a month. More than one fourth percent $(25.5 \%)$ male and 15.9 percent female of municipality said that they calls meetings and general assembly as a need based, 2 percent male and 2 percent female said that they calls meeting and general assembly once a month and 0.8 percent male and 0.6 percent female said that they calls meeting and general assembly two times of year, 9.3 percent male and 5.9 percent female of rural municipality said that they call meeting and general assembly as a need based. Comparing to three election areas, municipality calls more meeting and general assembly comparing to metropolitan city and rural municipalities (table 1).

Table 2: Distribution of respondents by reporting the cases related to women discussed in the meeting by sex

\begin{tabular}{|c|c|c|c|c|c|c|c|c|c|c|}
\hline \multirow{3}{*}{$\begin{array}{l}\text { Election Areas } \\
\text { Metropolitan } \\
\text { City }\end{array}$} & \multicolumn{10}{|c|}{ Women's related Case (problems) Solving Places } \\
\hline & \multicolumn{2}{|c|}{$\begin{array}{l}\text { Husband } \\
\text { wife quarrel }\end{array}$} & \multicolumn{2}{|c|}{$\begin{array}{l}\text { Property } \\
\text { related case }\end{array}$} & \multicolumn{2}{|c|}{ Divorce } & \multicolumn{2}{|c|}{$\begin{array}{l}\text { Mother in } \\
\text { law sister } \\
\text { in law in } \\
\text { quarrel }\end{array}$} & \multicolumn{2}{|c|}{ Total } \\
\hline & No. & $\%$ & No. & $\%$ & No. & $\%$ & No. & $\%$ & No. & $\%$ \\
\hline Male & 41 & 11.5 & 21 & 5.9 & 19 & 3.5 & 2 & 0.6 & 83 & 23.2 \\
\hline Female & 23 & 6.4 & 17 & 4.7 & 10 & 2.8 & 1 & 0.3 & 51 & 14.2 \\
\hline \multicolumn{11}{|l|}{ Municipality } \\
\hline Male & 31 & 8.7 & 64 & 17.9 & 6 & 1.7 & 2 & 0.6 & 103 & 28.8 \\
\hline Female & 15 & 4.2 & 45 & 12.6 & 4 & 1.1 & 3 & 0.8 & 67 & 18.7 \\
\hline \multicolumn{11}{|c|}{ Rural Municipality } \\
\hline Male & 10 & 2.8 & 19 & 5.3 & 4 & 1.1 & 0 & 0.0 & 33 & 9.2 \\
\hline Female & 2 & 0.6 & 17 & 4.7 & 2 & 0.6 & 0 & 0.0 & 21 & 5.9 \\
\hline Total & 122 & 34.2 & 183 & 51.1 & 45 & 10.8 & 8 & 2.3 & 358 & 100.0 \\
\hline
\end{tabular}

Source: Field Survey, 2076. 
In total, 34.2 percent respondents reported husband wife quarrel related cases, 51.1 percent respondents said that property related cases, and 10.8 percent said that divorce related cases and 2.3 percent said mother in law, sister in law quarrel related cases. However, highest (51.1\%) cases are property related and lowest (2.3\%) are mother in law and sister in law quarrel related .As metropolitan city, 11.5 percent male and 6.4 percent female said that they goes to metropolitan city when they have quarrel between husband and wife. Same way, 5.9 male and 4.7 percent female goes to metropolitan city for property related case, 3.5 percent male and 2.8 percent female said that they goes to metropolitan city for divorce cases and 0.6 percent male and 0.3 percent female goes to metropolitan city for solving the mother in law, sister in law's quarrel. Analyzing by municipality, 8.7 percent male and 4.2 percent female said that they goes to municipality when husband and wife have quarrel, 17.9 percent male and 12.6 percent female said they goes to municipality when they have property related cases, 1.7 percent male and 1.1 percent female said that they goes to municipality to solve the divorce cases and 0.6 percent male and 0.8 percent female said they goes to municipality to solve the mother in law and sister in law quarrel.

Table 3: Number of cases (problems) solved by local Government

\begin{tabular}{|l|l|l|l|l|l|l|l|}
\hline \multicolumn{1}{|c|}{ Metropolitan City } & \multicolumn{7}{|c|}{ No. of Cases } \\
\hline Total number of cases & $\mathbf{2}$ & $\mathbf{3}$ & $\mathbf{4}$ & $\mathbf{5}$ & $\mathbf{6}$ & $\mathbf{7}$ & $\mathbf{8}$ \\
\hline Women's Issues & & & & & & & \\
\hline Husband wife quarrel & 1 & 1 & 3 & 8 & 0 & 0 & 1 \\
\hline Property related case & 3 & 10 & 36 & 19 & 6 & 3 & 13 \\
\hline Mother in law and sister in law quarrel & 1 & 8 & 16 & 5 & 0 & 0 & 0 \\
\hline Municipality & & & & & & & \\
\hline Husband wife quarrel & 4 & 6 & 2 & 3 & 1 & 0 & 2 \\
\hline Property related case & 12 & 20 & 32 & 18 & 3 & 1 & 9 \\
\hline Mother in law and sister in law quarrel & 20 & 9 & 10 & 6 & 0 & 2 & 10 \\
\hline Rural Municipality & & & & & & & \\
\hline Husband wife quarrel & 1 & 1 & 2 & 4 & 0 & 0 & 0 \\
\hline Property related case & 14 & 13 & 7 & 4 & 0 & 1 & 3 \\
\hline Mother in law and sister in law quarrel & 0 & 1 & 1 & 0 & 1 & 0 & 1 \\
\hline
\end{tabular}

Source: Field Survey, 2076. 
The highest number of cases are related to property are solved by the all three level i.e. Metropolitan city, municipality and rural municipality. Same way, second highest cases are Mother in law and sister in law quarrel in metropolitan city and municipality but lowest are in rural municipality. However, majority of the cases are property related comparing to husband wife and mother in law and sister in law quarrel.

Table 4: The practice of discussion the women related issues in meeting and gathering of local government office and ward

\begin{tabular}{|c|c|c|c|c|c|c|}
\hline \multirow{3}{*}{ Characteristics } & \multicolumn{6}{|c|}{$\begin{array}{l}\text { Practice of discussion of Gender Issues in the } \\
\text { meeting/gathering }\end{array}$} \\
\hline & \multicolumn{3}{|l|}{ Male } & \multicolumn{3}{|c|}{ Female } \\
\hline & Yes & No & $\begin{array}{l}\text { Don't } \\
\text { Know }\end{array}$ & Yes & No & $\begin{array}{l}\text { Don't } \\
\text { Know }\end{array}$ \\
\hline Election area & $\%$ & $\%$ & $\%$ & $\%$ & $\%$ & $\%$ \\
\hline \multicolumn{7}{|l|}{ Metropolitan city } \\
\hline $\begin{array}{l}\text { Issue related women income gen- } \\
\text { erating }\end{array}$ & 22.1 & 0 & 1.1 & 14.0 & 0 & 0.3 \\
\hline $\begin{array}{l}\text { Leading role of women in all local } \\
\text { development sector }\end{array}$ & 15.4 & 6.1 & 1.7 & 10.9 & 2.0 & 1.4 \\
\hline $\begin{array}{l}\text { Equal participation of women in } \\
\text { all sectors }\end{array}$ & 23.0 & 0.0 & 0.0 & 14.2 & 0.0 & 0.0 \\
\hline $\begin{array}{l}\text { Do not participate of women in all } \\
\text { sector }\end{array}$ & 0.0 & 12.8 & 10.7 & 0.0 & 9.2 & 5.0 \\
\hline \multicolumn{7}{|l|}{ Municipality } \\
\hline $\begin{array}{l}\text { Issue related women income gen- } \\
\text { erating }\end{array}$ & 27.7 & 0 & 1.1 & 18.2 & 0 & 0.6 \\
\hline $\begin{array}{l}\text { Leading role of women in all local } \\
\text { development sector }\end{array}$ & 16.5 & 8.9 & 3.4 & 10.9 & 4.2 & 3.6 \\
\hline $\begin{array}{l}\text { Equal participation of women in } \\
\text { all sectors }\end{array}$ & 26.3 & 0.0 & 2.5 & 17.6 & 0.0 & 1.1 \\
\hline $\begin{array}{l}\text { Do not participate of women in all } \\
\text { sector }\end{array}$ & 0.0 & 21.5 & 7.3 & 0.0 & 14.2 & 4.5 \\
\hline \multicolumn{7}{|l|}{ Rural Municipality } \\
\hline $\begin{array}{l}\text { Issue related women income gen- } \\
\text { erating }\end{array}$ & 9.2 & 0 & 0 & 5.9 & 0.0 & 0 \\
\hline
\end{tabular}




\begin{tabular}{|l|l|l|l|l|l|l|}
\hline $\begin{array}{l}\text { Leading role of women in all local } \\
\text { development sector }\end{array}$ & 8.4 & 0 & 0.8 & 5.3 & 0.0 & 0.6 \\
\hline $\begin{array}{l}\text { Equal participation of women in } \\
\text { all sectors }\end{array}$ & 9.2 & 0.0 & 0.0 & 5.9 & 0.0 & 0.0 \\
\hline $\begin{array}{l}\text { Do not participation of women in } \\
\text { all sector }\end{array}$ & 0.0 & 6.7 & 2.5 & 0.0 & 3.9 & 2.0 \\
\hline & & & & & & \\
\hline
\end{tabular}

Source: Field Survey, 2076.

As metropolitan city, 22.1 percent male and 14 percent female said that the income generating related issues was raised, 15.4 percent male and 10.9 percent female said that raise the issue related to leading role of women in all local development sectors, 23 percent male and 14.2 percent female said that equal participation of women in all sectors. Some of the respondents that do not know what related issues was raised in metropolitan city meeting and gathering .As municipality, 27.7 percent male and 18.2 percent female said that women income generating issue was raised in the municipality meeting and gathering. 16.5 percent male and 10.9 percent female said that the leading role of women in all local development sector, 26.3 percent male and 17.6 percent female said that the meeting raised equal participation of women in all sectors related issue in the municipality's meeting and gathering. Some of them said that they do not know what issues they raised in the meeting of municipality. While analyze by rural municipality, 9.2 percent male and 5.9 percent female said that the women income generating issues are raised in the meeting, 8.4 percent male and 5.3 percent female said that raised the issues related to leading role of women in all local government sectors and 9.2 percent male and 5.9 percent female said that they raised the issue related to equal participation of women in all sectors. Some of the members do not know what issues were raised in the meeting of rural municipality. Comparing with three local governments, women income generating and equal participation of women in all sectors are the must raising issues of all three local government. 
In Lalitpur district, more than one third of the male respondents $(34.1 \%)$ and 18 percent female said that the gender responsive budget is to participated women planning, management and implementation, 24.6 percent male and 14.7 percent female said to increase women capacity, 28.4 percent male and 17.5 percent female said to ensure programme benefit and control by women, 4.3 percent male and 1.4 percent female said that the gender responsive budget is the women's employment and income generation and 4.7 percent male and 1.4 percent female said to decrease women's work load and improve the quality of women's work. And as Jhapa district, 31.3 percent male and 6.6 percent female said that gender responsive budget is to participated women planning, management and implementation, 31.3 percent male and 6.6 percent female said to increase women capacity, 31.3 percent male and 6.6 percent female said to ensure programme benefit and control by women, 20.9 percent male and 2.8 percent female said that women's employment and income generation and 20.9 male and 4.7 percent female said that the gender responsive budget is to decrease women's work load and improve the quality of women's work.

Table 5: Percentage of respondent's responses about the gender responsible budget

\begin{tabular}{|c|c|c|c|c|c|c|}
\hline \multirow{3}{*}{$\begin{array}{l}\text { Gender responsive budget } \\
\text { District } \\
\text { Lalitpur }\end{array}$} & \multicolumn{6}{|c|}{ Sex of the respondent } \\
\hline & \multicolumn{2}{|c|}{ Male } & \multicolumn{2}{|c|}{ Female } & \multicolumn{2}{|c|}{ Total } \\
\hline & No. & $\%$ & No. & $\%$ & No. & $\%$ \\
\hline $\begin{array}{l}\text { To participated women planning, } \\
\text { management and implementation }\end{array}$ & 72 & 34.1 & 38 & 18.0 & 110 & 52.1 \\
\hline To increase women capacity & 52 & 24.6 & 31 & 14.7 & 83 & 39.3 \\
\hline $\begin{array}{l}\text { To ensure programme benefit and } \\
\text { control by women }\end{array}$ & 60 & 28.4 & 37 & 17.5 & 97 & 46.0 \\
\hline $\begin{array}{l}\text { Women's employment and income } \\
\text { generation }\end{array}$ & 9 & 4.3 & 8 & 3.8 & 17 & 8.1 \\
\hline $\begin{array}{l}\text { To decrease women's work load and } \\
\text { improve the quality of women's work }\end{array}$ & 10 & 4.7 & 3 & 1.4 & 13 & 6.2 \\
\hline \multicolumn{7}{|l|}{ Jhapa } \\
\hline $\begin{array}{l}\text { To participated women planning, } \\
\text { management and implementation }\end{array}$ & 66 & 31.3 & 14 & 6.6 & 80 & 37.9 \\
\hline To increase women capacity & 66 & 31.3 & 14 & 6.6 & 80 & 37.9 \\
\hline
\end{tabular}




\begin{tabular}{|l|l|l|l|l|l|l|}
\hline $\begin{array}{l}\text { To ensure programme benefit and } \\
\text { control by women }\end{array}$ & 66 & 31.3 & 14 & 6.6 & 80 & 37.9 \\
\hline $\begin{array}{l}\text { Women's employment and income } \\
\text { generation }\end{array}$ & 44 & 20.9 & 6 & 2.8 & 50 & 23.7 \\
\hline $\begin{array}{l}\text { To decrease women's work load and } \\
\text { improve the quality of women's work }\end{array}$ & 44 & 20.9 & 10 & 4.7 & 54 & 25.6 \\
\hline
\end{tabular}

Source: Field Survey, 2076.

As metropolitan city, 27.5 percent male and 13.7 percent female said that gender responsive policy is to participated women planning, management and implementation, 18.5 percent male and 10.1 percent female said to increase women capacity, 18 percent male and 10 percent female said that to ensure program benefit and control by women, and 4.7 percent male and 1.4 percent female said that to decrease women's work load and improve the quality of women's work. However, highest (41.2\%) respondents said the gender responsive budget is to participated women planning, management and implementation.

As table 5, 30.3 percent male and 10.4 percent female said gender responsible budget is to participated women planning, management and implementation, 29.9 percent female and 10.4 percent female said to increase women capacity, 34.1 percent male and 13.7 percent female said to ensure programme benefit and control by women, 21.8 percent male and 6.2 percent female said women's employment and income generation and 16.6 percent male and 4.7 percent said to decrease women's work load and improve the quality of women's work. Highest percent of respondents said that the gender responsive budget is to ensure programme benefit and control by women and lowest percent of respondents said to decrease women's work load and improve the quality of women's work. 
Table 6: Percentage of respondents by types of problems reported on gender based programme actives by sex

\begin{tabular}{|c|c|c|c|c|c|c|c|}
\hline \multirow{3}{*}{$\begin{array}{l}\text { Types of Problems District } \\
\text { Lalitpur }\end{array}$} & \multicolumn{6}{|c|}{ Sex of respondents } & \multirow{3}{*}{$\begin{array}{c}\text { Female } \\
\text { Per } 100 \\
\text { males }\end{array}$} \\
\hline & \multicolumn{2}{|c|}{ Male } & \multicolumn{2}{|c|}{ Female } & \multicolumn{2}{|c|}{ Total } & \\
\hline & No. & $\%$ & No. & $\%$ & No. & $\%$ & \\
\hline $\begin{array}{l}\text { To demand the budget without policy } \\
\text { and act (Darkhane, Jatrapuja, picnic, } \\
\text { staff tour etc.) }\end{array}$ & 9 & 18.8 & 8 & 16.7 & 17 & 33.5 & 89 \\
\hline $\begin{array}{l}\text { To increase meeting incentive and } \\
\text { allowance TA/DA }\end{array}$ & 3 & 6.2 & 3 & 6.2 & 6 & 12.4 & 100 \\
\hline \multicolumn{8}{|l|}{ Jhapa } \\
\hline $\begin{array}{l}\text { To demand the budget without policy } \\
\text { and act (Darkhane, Jatrapuja, picnic, } \\
\text { staff tour, etc.) }\end{array}$ & 13 & 27.1 & 10 & 20.8 & 23 & 47.9 & 77 \\
\hline $\begin{array}{l}\text { To increase meeting incentive and } \\
\text { allowance TA/DA }\end{array}$ & 2 & 4.2 & 0 & 0.0 & 2 & 4.2 & 0 \\
\hline \multicolumn{8}{|l|}{ Election Area } \\
\hline \multicolumn{8}{|l|}{ Metropolitan city } \\
\hline $\begin{array}{l}\text { To demand the budget without policy } \\
\text { and act (Darkhane, Jatrapuja, picnic, } \\
\text { staff tour, etc.) }\end{array}$ & 6 & 12.5 & 6 & 12.5 & 15 & 25.0 & 100 \\
\hline $\begin{array}{l}\text { To increase meeting incentive and } \\
\text { allowance TA/DA }\end{array}$ & 2 & 4.2 & 2 & 4.2 & 4 & 8.4 & 100 \\
\hline \multicolumn{8}{|l|}{ Municipality } \\
\hline $\begin{array}{l}\text { To demand the budget without policy } \\
\text { and act (Darkhane, Jatrapuja, picnic, } \\
\text { staff tour, etc.) }\end{array}$ & 13 & 27.1 & 10 & 20.8 & 23 & 47.9 & 77 \\
\hline $\begin{array}{l}\text { To increase meeting incentive and } \\
\text { allowance TA/DA }\end{array}$ & 3 & 6.2 & 1 & 2.1 & 4 & 5.3 & 33.3 \\
\hline \multicolumn{8}{|l|}{ Rural Municipality } \\
\hline $\begin{array}{l}\text { To demand the budget without policy } \\
\text { and act (Darkhane, Jatrapuja, picnic, } \\
\text { staff tour, etc.) }\end{array}$ & 3 & 6.2 & 2 & 4.2 & 5 & 10.4 & 67 \\
\hline $\begin{array}{l}\text { To increase meeting incentive and } \\
\text { allowance TA/DA }\end{array}$ & 0 & 0.0 & 0 & 0.0 & & 0.0 & 0 \\
\hline
\end{tabular}

Source: Field Survey, 2076. 
While analyze the sex ratio by district, 89 female in 100 male of Lalitpur district and 77 female in 100 male of Jhapa district have reported the demand the budget without policy and act (Darkhane, Jatrapuja, Picnic, staff tour etc. and 100 female in 100 male reported the increase meeting incentive and allowance TA/DA. Same way, in Lalitpur district, 18.8 percent male and 16.7 percent female said that they faced problems of the demand the budged without policy and act ( Dar Khane, Jatra Puja, picnic, staff tour, etc. and same way 6.2 percent male and 6.2 percent female said they faced problems of increase meeting incentive and allowance TA/DA. In Jhapa district, 27.1 percent male and 20.8 percent female said that they faced the problems of demanded the budget without policy and act (Dar Khane, Jatra Puja, Pinnic, staff tour etc.). Furthermore, 4.2 percent male said that they faced the problems of increases meeting incentives and allowance TA/DA. Comparing these two districts, the respondents of Jhapa district faced more problems than Lalitpur district. As election area by sex ratio, 100 female in 100 male of metropolitan city have reported the problems of demand the budget without policy act (Darkhane, Jatra Puja, Picnic, staff tour etc. and same sex ratio said the increase meeting incentive and allowance TA/DA. 77 female in 100 male of municipality said they have problems of demand the budget without policy and act for Darkhane, Jatra Puja, picnic, staff tour etc. and another 33.3 female in 100 male said increase the meeting incentive and allowance TA/DA. And 67 female in 100 male of rural municipality said they have reported the problems to demand the budget without policy and act for Dar khane, Jatra Puja, picnic and staff tour etc. However, same sex ratio of metropolitan city has reported the highest problems. Same way, 12.5 percent male and 12.5 percent female of metropolitan city, said that they faced the problems of to demand the budget without policy and act (Darkhane, Jatra Puja, picnic staff tour etc.) and same way 4.2 percent male and 4.2 percent female said that they faced the problems of to increase meeting incentives and allowance TA/ DA. In metropolitan city, the local government personnel highly faced the problems of demand the budget without policy and act. In municipality, 27.1 percent male and 20.8 percent female said that they faced the problems of to demand the budget without policy and act (Darkhane, Jatra, Puja, picnic staff tour, etc.) and same way, 6.2 percent male and 2.1 female said that they faced the problems of to increase meeting incentives and 
allowance TA/DA. However, local government personnel highly faced the problems of demands the budget without policy and act (Darkhane, Jatra, Puja, picnic, staff tour etc. As rural municipality, 6.2 percent male and 4.2 percent female said that they have faced the problems of to demand the budget without policy and act (Darkhane, Jatra Puja, picnic staff.

\section{Conclusion}

Gender inclusion in local government, the practice of implementation of the formulated policies-program is gradually increasing in local government but still takes time to completely implementation but seems there is lacking of an effective awareness campaign. The gender empowerment training after they have elected for local government and lowest percentage are the respondents with aged 60 years and above. By sex, highest percent male than female said they have formulated the gender empowerment training program after they elected in local government. In this paper conclude that the total respondents, 35.3 percent are participation for plans formulation related to income generation progarammes, 31.4 percent plans are related to empowerment and leadership programmes, 21 percent plans are related to gender awareness and violence and only 2 percent plans are related to save cyber-crime. More than 6 percent respondents said that only ward representatives are involved in planning of program activities, 31.4 percent respondents said that only municipality authorities and ward representatives are involved and 59.3 percent respondents said that the local government representatives and all social activist are involved in planning of different program activities.

Gender inequality, including from legal gender-related restrictions, leads to the loss of growth opportunities, particularly in countries at earlier stages of development. The adverse effect of legal barriers to women's participation in economic activities remains significant for countries at different stages of development. Time is now for investing in women and ensuring countries and the world can honor commitments and achieve the Sustainable Development Goals agreed upon to ensure a prosperous life of women for generations to come. 


\section{References}

Armendáriz, B. (2010). The economics of microfinance. MIT Press, Cambridge. Gender Equality and Social Inclusion Working Group (GESI). (2017). A common framework for gender equality \& social inclusion gender equality and social inclusion working group. International Development Partners Group, Nepal.

International Labour Organization (ILO). (2000). ABC of women worker's rights and gender equality. Geneva

Moser, C. O. N. (1995). Gender planning and development: Theory, practice and training. Oxford University Press.

Moser, C. O. N. (1993). Gender planning and development: Theory, practice and training. Oxford University Press.

Razavi, S., \& Miller, C. (1995). From WID to GAD: Conceptual shifts in the women and development discourse. United Nations Research Institute, Oxford University Press.

United Nations (UN). (1995). Fourth world conference on women, Beijing; adoption of the Platform of Action.

United Nations (UN). (2013). The world declaration on women in local government. The Global Conference of Local Elected Women, Paris.

United Nations International Children's Emergency Fund (UNICEF). (2011). Prom

oting gender equality: An equity-based approach to programming. Specific Reference to Promotion and Entry in Administrative Services. Kathmandu, Nepal.

White, G. P. (1996). A survey and taxonomy of strategy-related performance measures for manufacturing. International Journal of Operations \& Production Management, 16 (3), 42-61. https://doi.org/10.1108/01443579610110486. 